\title{
Design of Maximum Power Point Tracking for Solar Collector Drying System: An Experimental Study
}

\author{
Saifuddin M. Jalil, Faizar Abdurrahman, Selamat Meliala, Rosdiana \\ Department of Electrical, Universitas Malikussaleh, Lhokseumawe, Indonesia
}

\begin{tabular}{l}
\hline \hline Article Info \\
\hline Article history: \\
Received Jun 5, 2018 \\
Revised Jul 9, 2018 \\
Accepted Jul 23, 2018 \\
\hline Keyword: \\
Microcontroller \\
MPPT \\
PV system \\
Solar collector \\
Solar energy
\end{tabular}

\begin{abstract}
This research describes the performance of maximum power point tracking as a solar collector of PV system integration for agriculture product drying system. The system comprises of solar collector, tracking PV array, the battery bank, the micro controller and the DC converter. This system is design to enhance the work of solar collector in drying process.. This design is hoped to be an appropriate system in order to ensure the maximum result by providing solar radiation energy. This paper shows the experiment data of the voltage and power response in positioning the PV to yield a maximum photovoltaic array output power of solar drying system device.
\end{abstract}

Copyright () 2018 Institute of Advanced Engineering and Science. All rights reserved.

\section{Corresponding Author:}

Saifuddin M. Jalil,

Department of Electrical,

Universitas Malikussaleh,

24351 Lhokseumawe, Indonesia

Email: saifuddin@unimal.ac.id

\section{INTRODUCTION}

Solar energy from the sun is a clean, secure and renewable energy which is available, this energy has been attract the need of sustainable energy which is can be implemented in various field of energy resource need, this energy is the solution to reduce the energy that come from the fossil fuel resource. The various application that utilize the solar energy as the resource such as source of electricity through PV system, solar collector as management of solar energy need that produce heat for drying process[1]. The lack of the solar collector is about the efficiency that reduce the output voltage conversion that result from the experimental work, to overwhelmed the efficiency of energy conversion from the solar of photo voltaic was introduce, the photo voltaic thermal (PVT) utilized active cooling method which is available for electricity and thermal condition. Modifying I-V the nonlinear calculation along with open circuit method also to have a better performance of Photo voltaic system[2].

The performance of drying using conventional is depend on the climate and temperature, research on optimizing system for drying system have been done by many research group of solar collector system [3], [4]. The need of appropriate system of drying system in resulting the farming product has encouraging the researcher in design hybrid system which is appropriately use in several condition[5]. Design of solar tracking system is the one of hybrid system in answering the need of continuity product of farming commodity, which is depend on drying process [6]. The moisture condition that's expected as preservative action in keeping the product suply, the ideal condition of drying process can be achieved during the summer. The Solar tracking system has been uses as the key in maintaining the result of farming product result [7].

The solar tracking is the one of solar drying sub system that uses in designing the robust desing of device in yielding the integrated solar collector, solar tracking principle work based on the sub system of electronic design based sensor that utilize to collect the solar radiation[8]. The uses of microcontroller in 
some of research is as the logic control, utilize as automatic system, the fuzzy logic control also choose by Angalaeswari, S., et al. as the integrated control of MPPT [9], to improve the function of solar device system as the one of selecting method to obtain a better performance of solar tracking system[10].

In addition the maximum power point tracking has been developed by previous research work using different control system to enhanced the performance of solar radiation tracking [11],[12], in producing the supply of solar energy to the PV, by generating the power electricity and resulting the heat radiation to the targeting object to be drying in the integrated system of solar collector, that utilize in farming product as the main device[13]. In this research the microcontroller choose due to it easy programable as the main logic processing unit in consecutively employ the research work of generating a better performance of the solar panel drying unit for agriculture products.

\section{DESIGN OF MPPT BLOCK DIAGRAM}

A solar tracking system tracks the position of the sun and maintains the solar photovoltaic modules at an angle that produces the maximum power output. Several solar tracking principles and techniques have been proposed to track the sun efficiently.The configuration block system on MPPT as shown in Figure.1 is a flow step proces of MPPT with the integrated system to yield a control function. The use of every component decides the performance of the whole system design. The sun position detect in several diferent angel that utilize the light dependent resistor (LDR) to sense the sun radiation light as the input for the microcontroller as the system feedback. The stepper motor as the mechanic device works in positioning the panel to obtain the maximum radiation of light as the input of drying solar panel system.

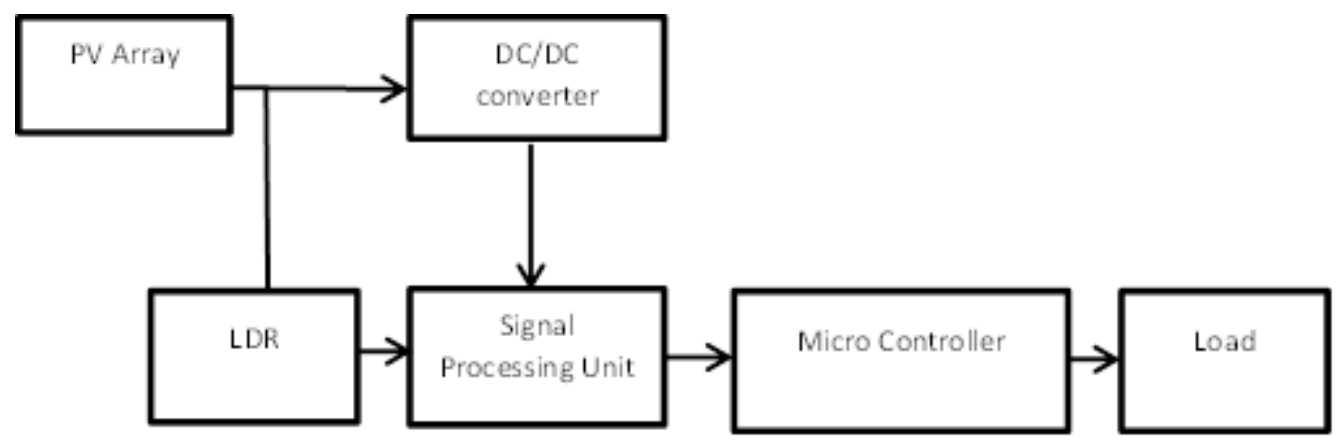

Figure 1. Block diagram system of MPPT

The conductance incremental method occurred based on the principle of maximum power result the formula as presented:

$$
\frac{d p}{d v}=-\frac{I}{V}
$$

The PV output power respectively $\mathrm{P}, \mathrm{V}$ and I respectively voltage, current and PV output power. According to Chiang et.al [14] the power slope $d P / d V$ use to calculate digital by sampling the PV array output current and voltage at following time interval (n-1) as shown below :

where; $P(n)=V(n) I(n)$

\section{RESULTS AND ANALYSIS}

The performance of MPPT was recorded and reveal as depict in graph. 2 and graph 3, the increment of power occurred in three different condition of measurement steps. The measurement is test in two sections of time during morning and afternoon time with different temperature. The response of energy receive shows the good response of performance of MPPT system, which is integrated with the solar drying system in tracking the solar position to absorb the radition as the input power. 


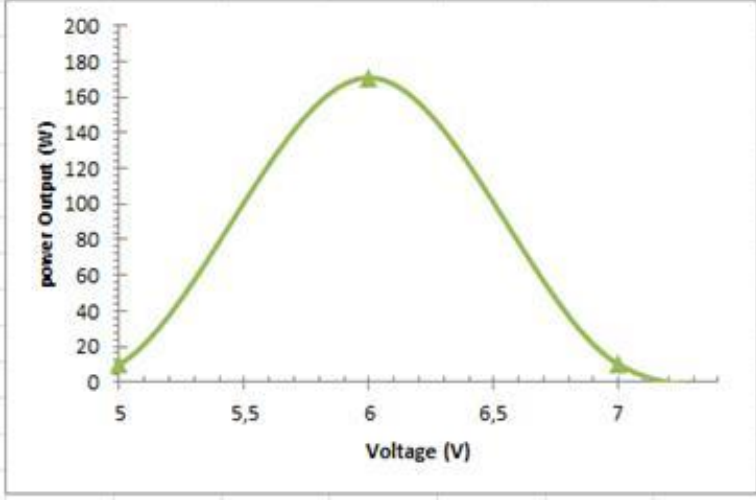

(a)

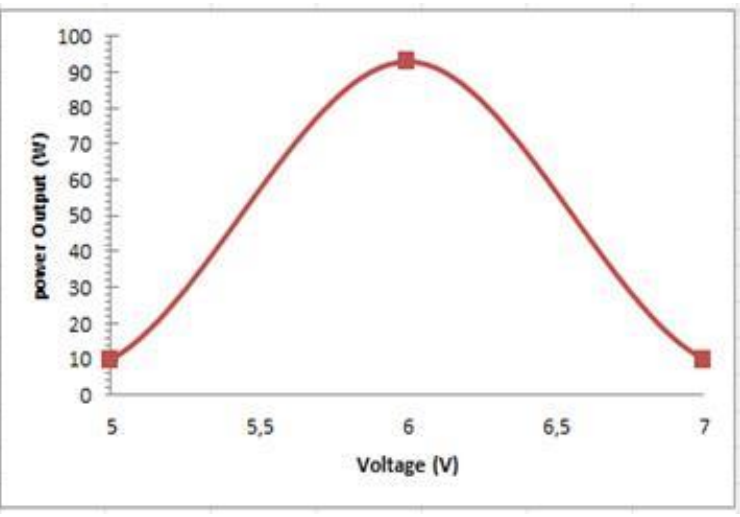

(b)

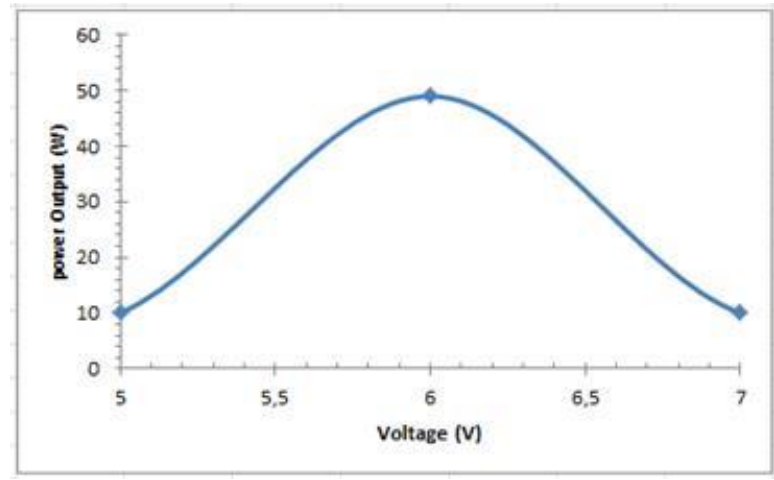

(c)

Figure 2. Response of photovoltaic array ouput (a).output power at temperature $20^{\circ} \mathrm{C}$ (b) output power receive at temperature $22{ }^{\circ} \mathrm{C}$ (c) output power at temperature $25^{\circ} \mathrm{C}$

The measured power depicted in graph Figure 2 of the MPPT behave at the certain temperature condition, the power rise due to different temperature level, the response of voltage and power obtain from the sun radiation due to different declination angel of solar panel, the voltage increment level rise along whith the energy receive from the sun light in the first experimental under the temperature of $20^{\circ} \mathrm{C}, 22{ }^{\circ} \mathrm{C}$ and, $25^{\circ} \mathrm{C}$.

The response graph of Figure 3 shown the increment of power receives from the sun radiation in different declination angel which is integrated with the MPPT test with different temperature. The temperature is influence the response of solar radiation which is tested under temperature $28^{\circ} \mathrm{C}, 30^{\circ} \mathrm{C}$ and $32^{\circ} \mathrm{C}$. As depicted in the response of voltage. The experimental reveal the proposed MPPT control increase the PV output power, according to the previous research the maximum power can be obtained from the $\mathrm{dc} / \mathrm{dc}$ converter only $1 \mathrm{KW} / \mathrm{m}^{2}[15]$.
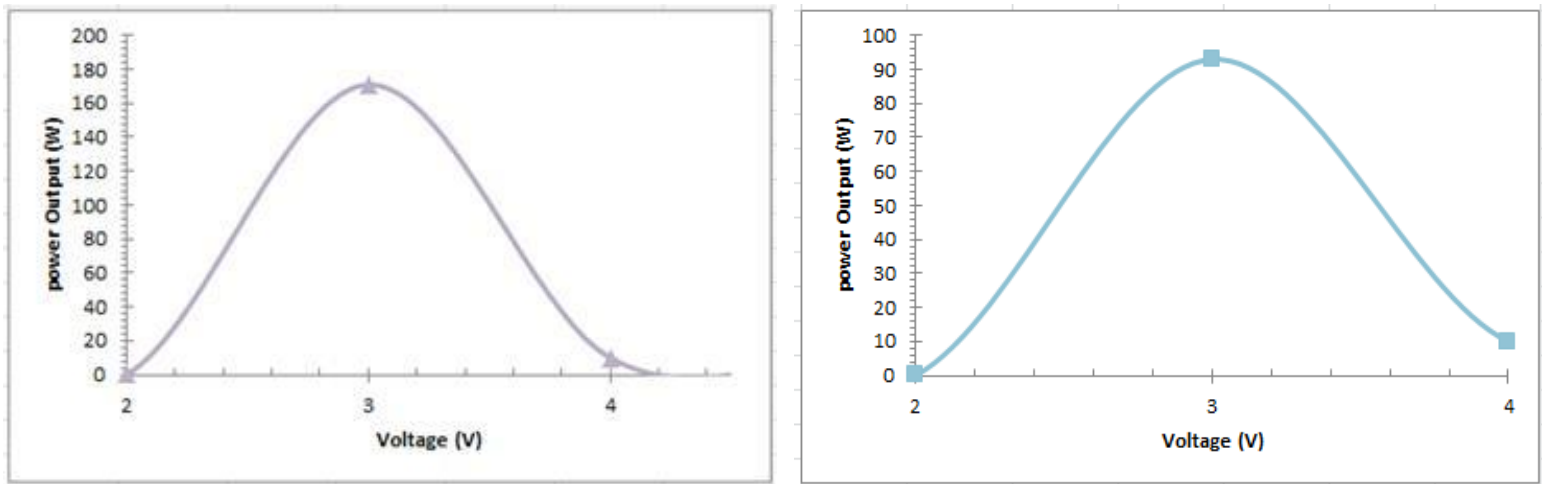

Design of Maximum Power Point Tracking for Solar Collector Drying System: An... (Saifuddin M. Jalil) 
(d)

(e)

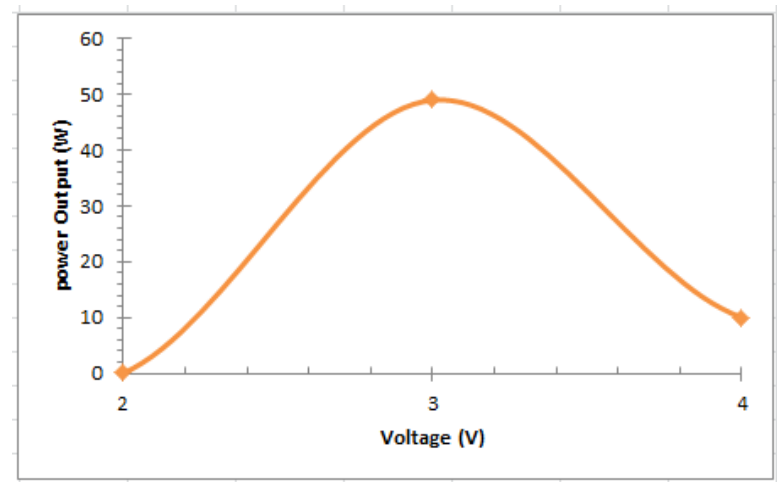

(f)

Figure 3. Response of photovoltaic array (d).output power at temperature $28^{\circ} \mathrm{C}$ (e) output power receive at temperature $30^{\circ} \mathrm{C}$ (f) output power at temperature $32^{\circ} \mathrm{C}$

\section{CONCLUSION}

The MPPT prototype has been designed in obtaining an initial result of a better performance of solar drying collector based on integrated system of MPPT, in addressing the drawback of single PV system using micro controller as the main logic control in maintaining the performance of the whole drying system of solar collector. The result show in figure 2 and figure 3, MPPT is the system that utilized in improving the result of power receive and voltage in different condition of temperature.

\section{ACKNOWLEDGEMENTS}

The authors would like to thank Malikussaleh University for the laboratory equipment and Ministry of Research Technology and Higher Education Republic of Indonesia for the research grant program under the grant of Penelitian Strategis Nasional No:04/UN45.7/PL/II/2018

\section{REFERENCES}

[1] Nadia, A.-R., N.A.M. Isa, and M.K.M. Desa, Advances in solar photovoltaic tracking systems: A review. Renewable and Sustainable Energy Reviews, 2017.

[2] Ibrahim, A., et al., Efficiencies and improvement potential of building integrated photovoltaic thermal (BIPVT) system. Energy Conversion and Management, 77: p. 527-534, 2014.

[3] Fudholi, A., et al., Energy and exergy analyses of solar drying system of red seaweed. Energy and Buildings, 68: p. 121-129, 2014.

[4] Parida, B., S. Iniyan, and R. Goic, A review of solar photovoltaic technologies. Renewable and sustainable energy reviews, 15(3): p. 1625-1636,2011.

[5] Hua, C.-C., Y.-H. Fang, and C.-J. Wong, Improved solar system with maximum power point tracking. IET Renewable Power Generation, 2018.

[6] Fudholi, A. and K. Sopian, Review on Solar Collector for Agricultural Produce. International Journal of Power Electronics and Drive Systems (IJPEDS), 9(1): p. 414-419, 2018.

[7] Fudholi, A., et al., Review of solar dryers for agricultural and marine products. Renewable and Sustainable Energy Reviews, 14(1): p. 1-30, 2010.

[8] Fudholi, A., et al., Primary Study of Tracking Photovoltaic System for Mobile Station in Malaysia. International Journal of Power Electronics and Drive Systems (IJPEDS), 9(1): p. 427-432, 2018.

[9] Angalaeswari, S., et al., Efficient Power Management of Grid operated MicroGrid Using Fuzzy Logic Controller (FLC). Energy Procedia, 117: p. 268-274, 2017.

[10] Jiang, Y., J.A.A. Qahouq, and T.A. Haskew, Adaptive step size with adaptive-perturbation-frequency digital MPPT controller for a single-sensor photovoltaic solar system. IEEE transactions on power Electronics, 28(7): p. 3195 3205, 2013.

[11] Laagoubi, T., M. Bouzi, and M. Benchagra, MPPT and Power Factor Control for Grid Connected PV Systems with Fuzzy Logic Controllers. International Journal of Power Electronics and Drive Systems (IJPEDS),. 9(1): p. 105113,2018

[12] Nsengiyumva, W., et al., Recent advancements and challenges in Solar Tracking Systems (STS): A review. Renewable and Sustainable Energy Reviews, 81: p. 250-279, 2018. 
[13] Megantoro, P., R. Budiarto, and I.E. Prabowo, Design of MPPT Based Microcontroller Using Algorithm of Constant Voltage and Perturb \& Observ also Buck Converter with Fuzzy Control.

[14] Chiang, S.-J., K. Chang, and C. Yen, Residential photovoltaic energy storage system. IEEE Transactions on industrial electronics, 45(3): p. 385-394. 1998.

[15] Koutroulis, E., K. Kalaitzakis, and N.C. Voulgaris, Development of a microcontroller-based, photovoltaic maximum power point tracking control system. IEEE Transactions on power electronics, 16(1): p. 46-54, 2001.

\section{BIOGRAPHIES OF AUTHORS}
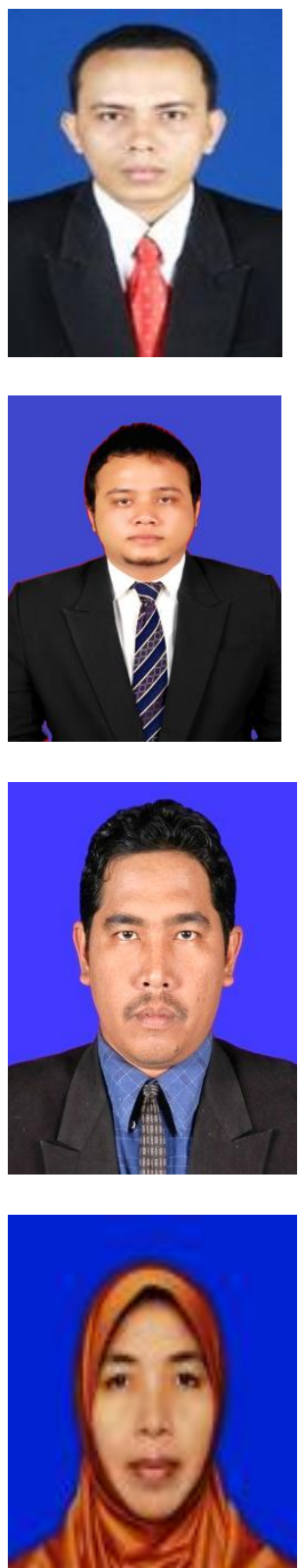

Saifuddin M.jalil , Graduated from Faculty of Mathematics and Natural Sciences Department of Physics, Syiah Kuala University (UNSYIAH) in 2000. Graduated of Master in Faculty of Engineering Department of Microelectronics University Kebangsaan Malaysia (UKM) 2008. He is currently a permanent lecturer at the Department of Electrical Engineering, University of Malikussaleh. Teaching courses in Industrial Electronics, Microprocessors, Microcontroller Applications, and Engineering Physics. Active Write an international article. publication of The effect of surface texturing on GaAs solar cell using TCAD tools and The effect of electrical properties by texturing surface on GaAs solar cell efficiency

Faizar Abdurahman graduated from Department of Electical Engineering Of Malikussaleh University in 2010. Graduated of Master of Science from University Kebangsaan Malaysia in Faculty of Engineering department of Electric, Electrical and System Engineering on 2016 in research mode of study. While pusrusing master study he also works as Graduate Resarch Assistant. Acatively involve in Research group of Photonic and physic material and appointed as member of editor board of TEKNOKA, he have been published some of research articles in ISI index and Scopus since 2014.

Selamat Meliala graduated from Faculty of Engineering of Electrical Engineering Department Unimal (Malikussaleh University) in 2001. Graduated of Master in Faculty of Engineering of Electrical Engineering Department North Sumatera University (USU) 2011. He is currently a permanent lecturer Engineering at the Department of Electrical Engineering, University of Malikussaleh. Teaching courses in Electrical Engineering Department of Malikussaleh University on High Voltage Engineering, Basic Digital Techniques, Basic Electrical Techniques. Active Write and national article Publication of Simulation of Series Active Filter to Compensate Harmonics in Low Voltage Line System. Major Research are Power Quality, Renewble Energy and Power System.

Rosdiana, Graduated from faculty of psysical engineering in Technology Institut of Sepuluh Nopember (ITS) Surabaya. And master in Electrical Engineering in ITS Surabaya in 2005. She teaches in Electrical Engineering as a permanent lecturer. Some subjects are electromagnetics, signal processing, image ànd multimedia processing, telematics and SCADA. Actives as a writer in international article publications of signal processing and telematics telecommucation. 